\title{
Confusion over live/dead stainings for the detection of vital microorganisms in oral biofilms - which stain is suitable?
}

\author{
Lutz Netuschil $^{1 *}$, Thorsten M Auschill ${ }^{2}$, Anton Sculean $^{3}$ and Nicole B Arweiler ${ }^{1}$
}

\begin{abstract}
Background: There is confusion over the definition of the term "viability state(s)" of microorganisms. "Viability staining" or "vital staining techniques" are used to distinguish live from dead bacteria. These stainings, first established on planctonic bacteria, may have serious shortcomings when applied to multispecies biofilms. Results of staining techniques should be compared with appropriate microbiological data.

Discussion: Many terms describe "vitality states" of microorganisms, however, several of them are misleading. Authors define "viable" as "capable to grow". Accordingly, staining methods are substitutes, since no staining can prove viability.

The reliability of a commercial "viability" staining assay (Molecular Probes) is discussed based on the corresponding product information sheet: (I) Staining principle; (II) Concentrations of bacteria; (III) Calculation of live/dead proportions in vitro. Results of the "viability" kit are dependent on the stains' concentration and on their relation to the number of bacteria in the test. Generally this staining system is not suitable for multispecies biofilms, thus incorrect statements have been published by users of this technique.

To compare the results of the staining with bacterial parameters appropriate techniques should be selected. The assessment of Colony Forming Units is insufficient, rather the calculation of Plating Efficiency is necessary. Vital fluorescence staining with Fluorescein Diacetate and Ethidium Bromide seems to be the best proven and suitable method in biofilm research.

Regarding the mutagenicity of staining components users should be aware that not only Ethidium Bromide might be harmful, but also a variety of other substances of which the toxicity and mutagenicity is not reported.

\section{Summary:}

- The nomenclature regarding "viability" and "vitality" should be used carefully.

- The manual of the commercial "viability" kit itself points out that the kit is not suitable for natural multispecies biofilm research, as supported by an array of literature.

- Results obtained with various stains are influenced by the relationship between bacterial counts and the amount of stain used in the test. Corresponding vitality data are prone to artificial shifting.

- As microbiological parameter the Plating Efficiency should be used for comparison.

- Ethidium Bromide is mutagenic. Researchers should be aware that alternative staining compounds may also be or even are mutagenic.
\end{abstract}

Keywords: Dental plaque, Biofilm, Microorganisms, Viability state, Vital fluorescence, Bacterial viability kit, Mutagenicity

\footnotetext{
* Correspondence: lutznetuschil@web.de

${ }^{1}$ Department of Periodontology, Dental School, Philipps-University Marburg,

Marburg, Germany

Full list of author information is available at the end of the article
} 


\section{Background}

The definition of the so-called "viability state(s)" of microorganisms has been a matter of confusion and discussion for decades (for a glimpse of the plethora of literature see [1-5]). Recently two manuscripts discussed this topic. Hannig et al. [6] investigated the influence of a novel mouthwash containing hydroxyapatite microclusters on bacterial adherence by using the BacLight ${ }^{\text {TM }}$ live/dead staining technique. Tawakoli et al. [7] compared different live/dead stainings "for detection and quantification of adherent microorganisms" in the initial oral biofilm. In line with earlier literature these two articles demonstrate that serious attempts have been made in the past decades to define the different states between dead and live (marine and oral) microorganisms, and that "viability staining" or "vital staining techniques" have been and are still used as a trial to overcome the problem of distinguishing between live and dead microorganisms in biofilms.

In recent years more and more scientists in dental biofilm research have become familiar with commercially available vitality/viability stains, especially the BacLight Assay (BLA; BacLight ${ }^{\text {Ts }}$ live/dead staining technique). However, this staining principle has severe shortcomings when applied to undefined natural multispecies biofilm samples. Results of this and other staining techniques should be compared to classical microbiological techniques like the assessment of colony forming units (CFU) and, more reliable, the calculation of bacterial plating efficiency (PE). These comparisons with a "gold standard" are quite rare when commercial kits are used in biofilm research. Furthermore, components of these vital stains may be potentially mutagenic.

In summary, the purpose of this manuscript is to debate the basis, usefulness and the risk of "viable" and "vital" stains especially in biofilm research, with specific attention to natural dental biofilms and vital fluorescence staining with Fluorescein Diacetate/Ethidium Bromide [8]. From a scientific point of view, it is important that data derived from such staining techniques should reflect the bacterial status correctly.

\section{Discussion}

\section{What is the root of the problem?}

From a holistic point of view the debate covers different levels. First, the discrimination of dead or alive microorganisms represents a crucial problem in (environmental) bacteriology. This basic problem has existed for decades and has not yet been solved. In this respect, the terms "vitality" and "viability" are often used and quite often mixed - some researchers completely interchange these terms [9].

Second, "vital stains" are generally only surrogates, but are quick and simple devices in studies examining, for example, the antibacterial effect of substances. Here the problem is the large variety of staining substances and thus of staining principles, so that the "plethora of choices adds to confusion" [10]. Similarly Pamp et al. [11] state: "More recently developed stains, such as the Syto stains .... can efficiently stain cells in virtually any color of the rainbow". That might sound humorous - but merely reflects the problem. As just mentioned, Tawakoli et al. [7] used combinations of several stains (for example FDA, cFDA, TCFDA, EB, as well as SYTO 9/PI, Sytox red, besides Calcein AM). Davey [10] also refers to FDA, PI and SYTO 9, but moreover to substances like SYTO green I, DIBAC4, pyronine Y, rhodamine 123 and thiazole orange. It is no wonder that this author [10] refers to another four reviews only to inform about the "modus operandi" of the different fluorescent stains and the "huge diversity of possibilities in terms of stain selection, concentration, staining time, etc".

When analyzing further, the problem becomes even more complex. Some authors criticize the limited use of propidium iodide (PI) as a cell viability (sic!) indicator $[12,13]$, while others monitored striking differences between SYTO 9 and SYTO 12 regarding the influence of porins on uptake kinetics of these dyes [14]. This means that when antibacterial substances disturbing the cell membrane integrity are assessed the use of those vital staining techniques may be misleading. An inherent aspect of this problem, namely the suitability of staining methods, is the dependency on the stains' concentrations of the results (see later).

Third, the users are for the most part unfortunately unaware that such "seductive" tests have only been validated for a very limited number of bacterial species [13,15]. From 15000 "hits" (250 reviews) generated in PubMed by asking for "flow cytometry \& bacteria", only three were left after filtration of the database when using "biofilm" as an additional tracing term. None of this three articles contributes to the debate.

It is crucial that "vital stains" and, much more important, their combinations are directly compared to conventional bacteriological data. As discussed later in detail this cannot be the assessment of CFU, but of PE. In dentistry some corresponding work has been completed using single or a lucid number of species in vitro without conducting bacteriological tests [6,16-18], while some companies used this staining method trusting per $s e$ in its reliability $[19,20]$. When the SYTO 9/PI combination was in fact related to corresponding microbiological assessments the outcome was inconsistent [21-23]. In our opinion it is impossible to find out studies where particular examples of these vital stains and its combinations were properly compared and related to microbiological data concerning natural multispecies biofilms like dental plaque. 
Finally, the dyes may be or are toxic or mutagenic. With respect to the list of compounds, as previously mentioned and excerpted from [7] and [10], it must be determined whether there is a harm or risk in the use of these substances.

\section{Viability versus Vitality}

Netuschil [8] recorded 49 terms to describe "vitality states" of microorganisms (for example: active microbes, cryptic growth, direct viable count [DVC], progressive dormancy, vegetative dormancy, dwarf cells, moribund cells, nonculturability, nonplateable, stasis survival, reproductive viability, viable but not culturable [VBNC], non-viable but resuscitable, vital, viviform, etc.) as cited in 34 different corresponding publications [1,2,4,24-54] (cf. Table 1). While the table displays references from 1962 up to 1998 , the debate is older and was already relevant at the turn of the $19^{\text {th }}$ to the $20^{\text {th }}$ century [55-60]. One example is the "Great Plate Count Anomaly" [61,62] see also [63]. Even at that time vital stainings were debated to be used as a trial to overcome the shortcomings of culture techniques [64-68]. It seems that the past discussion [69] was "revitalized" at the turn of this century [41,70-78]. Of note is that some terms (e.g., dormant, VBNC) are even relevant when referring to probiotic bacteria $[79,80]$.

Unfortunately, several of the terms found and used in publications are incorrect, misleading or even paradoxical, especially the often used term "viable but not culturable (VBNC)", which blurs the line between vitality and viability. To minimize confusion as much as possible we refer to Kaprelyants et al. [4]: "Several classifications of the physiological states of microorganisms have been presented. We have previously suggested [3] that all the cell types considered could be reduced to three groups, as follows: 'viable' to refer to a cell which can form a colony on an agar plate, 'vital' to refer to one which can only do so after resuscitation and 'non-viable' to refer to a cell which cannot do so under any tested condition. According to this terminology, dormant cells are vital" (see Table 2).

In accordance with [4] we define "viable" strictly as "capable to grow". In this respect any other tests, for example elongation tests (DVC; [50]) or staining methods, are merely proxies, since no kind of staining can prove viability. Thus, the term "viability stain" is a misnomer per definitionem and these stains should correctly be named "vital stains". Unfortunately, the misnomer is frequently used by Invitrogen Ltd. (BacLight ${ }^{\mathrm{TM}}$ ), and is consequently - but incorrectly - adopted by the users of these vitality tests.

The BacLight ${ }^{\mathrm{TM}}$ bacterial viability kit (BacLight Assay, BLA) According to the manufacturer [81] BLA consists of two stains, propidium iodide (PI) and SYTO 9, which both stain nucleic acids. SYTO9 is a green fluorescing intercalating membrane permeable molecule and stains all cells. In contrast, PI is a red intercalating stain and is membrane impermeable, and is therefore excluded by "healthy" cells. The manufacturer describes that PI has a stronger affinity to nucleic acids than SYTO 9; thus, when both stains are present within a cell, SYTO 9 will be displaced from nucleic acids and the cell(s) will fluoresce in red. To prove the mechanism Stocks [82] conducted "cell-free" physicochemical measurements with the "Viability Stain, BacLight", and could reveal that the staining principle is not that simple. This author established a so-called fluorescence resonance energy transfer (FRET), though, under certain staining conditions, SYTO 9 emission surpasses the PI emission. Increasing the SYTO 9 concentration may thus enhance the PI emission, causing a double staining of cells. Stocks [82] emphasizes several times that for an interpretation of the staining outcome "the relative concentrations of PI, SYTO9 and DNA were of crucial importance" and "that appropriate control or validation experiments (should be) performed". Double staining and/or FRET was also documented by other authors $[41,83]$, who examined viability parameters of viable and formaldehyde-killed or UVA-treated cultures, respectively. The following discussion of the MOLECULAR PROBES manual should be viewed in this context.

Concerning the reliability of the "viability kit" used in biofilm research we would like to directly cite the product information sheet(s) of MOLECULAR PROBES 2001; Product Information LIVE/DEAD $\bullet$ BacLight $^{\mathrm{TM}}$ Bacterial Viability Kit, Revised: 26-January-2001, as well as Revised: 15-July-2004 (whereby the latter represents the most current version in October 2013) [81]:

(I) "... stains differ both in their spectral characteristics and their ability to penetrate healthy bacterial cells. When used alone, the SYTO 9 stain generally labels all bacteria in a population - those with intact membranes and those with damaged membranes. In contrast propidium iodide penetrates only bacteria with damaged membranes, causing a reduction in the SYTO 9 stain when both dyes are present. Thus, with an appropriate mixture of the SYTO 9 and propidium iodide stains, bacteria with intact cell membranes stain fluorescent green, whereas bacteria with damaged membranes stain fluorescent red."

(II) "Staining Bacteria with either Kit L7007 or L7012 4.1 Adjust the E. coli suspensions (live and killed) to $1 \times 10^{8}$ bacteria/mL or the S. aureus suspensions (live and killed) to $1 \times 10^{7}$ bacteria/ $\mathrm{mL}$. S. aureus suspensions typically should be 10-fold less concentrated than E. coli for fluorescence microscopy." Hence the numbers of E. coli and S. aureus differ by one logarithm. 


\begin{tabular}{|c|c|}
\hline Acclimation [30] & "Quiescent cells" [17] \\
\hline Active microbes [20] & Resuscitation [3,4,15,24,28-31] \\
\hline Alive, "aliveness" [15] & $\begin{array}{l}\text { "Shut down cells", "shut down state" } \\
{[17]}\end{array}$ \\
\hline "Anabiotic (dormant) state" [15] & Somnicells $[8,11,30]$ \\
\hline "Bags of enzymes" [4,12] & Starvation $[10,17,29]$ \\
\hline Cryptic growth $[24,26,27,29]$ & - "True starvation" [15] \\
\hline Culturable, culturability $[4,10,11,31]$ & "Substrate accelerated death", "substrate \\
\hline $\begin{array}{l}\text { - Nonculturable, nonculturability } \\
{[22,24]}\end{array}$ & Accelerated stress" [6,15,26,29,31,33] \\
\hline Debilitation [9] & Survival $[5,11,20,22,29]$ \\
\hline $\begin{array}{l}\text { Dead, death } \\
{[3,4,9,11,15,16,20,26,29]}\end{array}$ & - "Survivability" [3] \\
\hline - "Death phase" [15,29] & - "Stasis survival" [25] \\
\hline "Die-off" [31] & Viable $[3,10,15,16,18,30,31]$ \\
\hline \multirow{2}{*}{$\begin{array}{l}\text { Direct viable count (DVC), DVC } \\
\text { method }[3,4,10,15,18,29-31,34]\end{array}$} & - Non viable $[3,15,16,20]$ \\
\hline & $\begin{array}{l}\text { Viability } \\
{[3,4,6,9,12,13,15,16,19,22,23,26,29]}\end{array}$ \\
\hline $\begin{array}{l}\text { Dormant, dormancy } \\
{[11,12,15,20,23,28-30,32]}\end{array}$ & - "Apparent viability" [6,15] \\
\hline - "Progressive dormancy" [1,30] & - "Reproductive viability" [23] \\
\hline - "Vegetative dormancy" [15] & - "True viability" [6] \\
\hline $\begin{array}{l}\text { Dwarf cells, inactive dwarfs, } \\
\text { ultramicrobacteria }[6,14,15,29,32]\end{array}$ & $\begin{array}{l}\text { "Viable but nonculturable" (VBNC) } \\
{[3,4,8,10,12,15,16,21,22]}\end{array}$ \\
\hline Growth arrest [25] & - VBNC hypothesis $[2-4,7]$ \\
\hline "Killer phenotype" [15] & $\begin{array}{l}\text { - VBNC state } \\
{[3,4,10,22,24,29,31,33,34]}\end{array}$ \\
\hline Lysis [20] & - "Viable but nonrecoverable" [31] \\
\hline Moribund cells [29] & - "Non-viable but resuscitable" [16] \\
\hline 'Nonplateable" [24] & - "Unculturable but viable" [28] \\
\hline Protistan grazing [11] & Vital, vitality $[15,16,26]$ \\
\hline “Pseudosenescent” [29] & Viviform $[11,30]$ \\
\hline
\end{tabular}

\section{References:}

'BARCINA et al. 1989 [24]

${ }^{2}$ BARER et al. 1993 [25]

${ }^{3}$ BOGOSIAN et al. 1996 [26]

${ }^{4}$ BOGOSIAN et al. 1998 [27]

${ }^{5}$ BOWDEN \& HAMILTON

$1998[28]$

${ }^{6}$ BUTTON et al. 1993 [29]

${ }^{7}$ COLWELL 1993[30]

${ }^{8}$ COLWELL et al. 1985 [31]

${ }^{9}$ DAWE \& PENROSE 1978 [32]

${ }^{10}$ DUNCAN et al. 1994 [33]

${ }^{11}$ GONZÁLES et al. 1992 [34]

${ }^{12}$ GRIBBON \& BARER 1995 [35]

${ }^{13}$ HÖFLE 1983 [36]
Table 1 Terms used to describe "vitality states" of microorganisms (from [8]) (Continued)

\begin{tabular}{ll}
\hline${ }^{14} \mathrm{HOOD}$ et al. 1987 [37] & ${ }^{31}$ ROSZAK et al. 1984 [51] \\
${ }^{15}$ KAPRELYANTS et al. 1993 [4] & ${ }^{32}$ STEVENSON 1978 [52] \\
${ }^{16}$ KELL et al. 1991 [38] & ${ }^{33}$ WHITESIDES \& OLIVER 1997 [53] \\
${ }^{17}$ KOCH 1996 [39] & ${ }^{34}$ WILSON \& LINDOW 1992 [54] \\
\hline
\end{tabular}

(III) Lastly, due to (I) a mixture of 50\% living and 50\% dead bacteria does not normally lead to a 50/50 green/red fluorescence. And vice versa: $50 \%$ of green fluorescing bacteria in a sample does not mean that there are $50 \%$ vital cells. Therefore, "green/red fluorescence ratios (have to be) calculated for each proportion of live/dead E. coli."

This last point was confirmed by Hannig et al. [6] in their paper concerning the viability of $S$. mutans in vitro. They determined that an "initial concentration of viable bacteria in the assay" of 50\% leads to different "ratio emission vital/emission dead bacteria" values of about 9.5, 6.5 or 8.0 in their NaCl-control samples. Furthermore, Hannig et al. [6] state that "the proportion of avital bacteria increased as indicated by the ratio of avital to vital cells. It ranged between $0.1 \ldots$ and ... 29.0 ... After rinsing with chlorhexidine, the ratio amounted to 190 (6 h) or $10.2(12 h) .$. " Taking the information of their Figure one into account, it remains unclear what these different ratios actually may mean in terms of "real" vitality values.

In summary, the three above-mentioned points described in the BLA user's manual show that, in accordance with Stocks [82], an "appropriate mixture" of the two stains must be determined and established for any single species of bacteria before using them in an experiment. This may be possible in an in vitro situation, where the BLA may help to save time in the long run following critical, careful, and time consuming calibration steps for each individual bacterial species. However, this is impossible to manage in naturally occurring

Table 2 "Glossary of terms used to describe the 3 major physiological states defined herein" (cited from [3])

\begin{tabular}{ll}
$\begin{array}{l}\text { Physiological } \\
\text { state }\end{array}$ & Phenotype \\
\hline Viable & Capable of division; will form a colony on an agar plate. \\
Vital or dormant & $\begin{array}{l}\text { Unable to divide or to form a colony on an agar plate } \\
\text { without a preceding resuscitation phase. }\end{array}$ \\
Non-viable & $\begin{array}{l}\text { Incapable of division; will not form a colony on an } \\
\text { agar plate under any tested condition. }\end{array}$ \\
\hline
\end{tabular}

We use the phrases 'starvation' or 'starving cells' to refer to the environmental conditions under which cells are incubated, rather than to a physiological state. Thus starved cells (or cells that have suffered other stresses) may or may not be dormant. Despite historical usage of these terms, the phrases 'direct viable count' and 'viable-but-non-culturable' are misnomers, since such cells are not viable as defined above. 
biofilms due to the uniqueness of the plaque matrix biofilms where in reality there may be more or less than 1000 different microbial species [84]. Moreover the application of the SYTO 9/PI stain is not considered suitable for biofilms, because of diffusion phenomena due to exo-polymers that result "in an underestimation of viable counts" [21].

However, there seems to be an additional drawback. Giertsen et al. [23] criticized considerable discrepancies between expected biofilm vitality and the outcome of the SYTO 9/PI staining method. Moreover, these authors described an instable behavior and a change of the staining color from green to red, i.e. towards monitoring more "dead" bacteria. Just recently these findings were explained by Tawakoli et al. [7] postulating that stained cells lost their viability shortly after intercalation of the dyes, writing: "This hypothesis was confirmed by the TEM analysis in the current study (Figure two). The images showed immense lysis and destruction of the adherent cells ...."

Table 3 lists a plethora of studies [5-7,9,16-20,22,23,41, $71,73,82,83,85-98]$ that used the BLA. However, in almost all studies it had to cleared up (a) if plaque-like biofilms or, at least, saliva samples were evaluated, or if the investigations were made with single bacterial species and/or artificial (monospecies) biofilms; (b) if the staining regime of the biofilm samples was adjusted according to the BLA manual (validation); (c) which dilution factor was used between SYTO 9 and PI, due to a validation procedure according to (b); (d) how the incubation procedure was followed, especially the incubation time of the bacterial samples together with the stains' mixture; (e) whether the results of the BLA were compared to other parameters, and if the latter were appropriate (g) or not (f); (h) if the BLA results fit with the other parameters (whether appropriate or not). Last not least we were interested (i) whether the BLA results met the expectations of the users.

From the 30 investigations listed in Table 3 one half (15) was classified in the rubric "plaque-like biofilm". This high portion is due to the fact that we endeavored to consider literature concerning oral biofilms. Natural saliva was also included e.g. [89-91] as well as "microcosm plaques", which were grown in an artificial mouth and/or were for example established from saliva $[20,71,92]$ or from a subgingival plaque sample [96]. Some other studies dealt with deep-sea sediment bacteria or wastewater samples [73,93], which were considered by us as natural multispecies systems.

It is astonishing, but expected, that only five studies were based on a preceding validation procedure (line (b) in Table 3) $[6,19,83,92,93]$, from which two cases were even questionable $[19,93]$. Nevertheless, a calibration could be assumed there. The description of Filoche et al. [92] clarifies the laborious methodology (cf. their Materials \& Methods section, paragraphs 2.5 Generation of the
Table 3 Background information concerning the use of the BacLight ${ }^{\circledR}$ assay (BLA) for assessment of (dental) biofilm vitality

\begin{tabular}{|c|c|}
\hline $\begin{array}{l}\text { Studies using the BLA } \\
(\mathrm{n}=30)\end{array}$ & {$\left[5-7,9,16-20,22,23,41,71,73,82^{*} 83,85-98\right]$} \\
\hline \multirow{2}{*}{$\begin{array}{l}\text { (a) Were plaque-like } \\
\text { biofilms evaluated? }\end{array}$} & No: $[5,16-18,22,23,41,82,83,86,87,93,96-98]$ \\
\hline & Yes: $[6,7,9,19,20,71,73,85,88-92,94,95]$ \\
\hline \multirow[t]{2}{*}{ (b) Validation } & $\begin{array}{l}\text { No: } \\
{[5,7,9,16-18,20,22,23,41,71,73,82,85-91,94-98]}\end{array}$ \\
\hline & Yes: [6, 19?, 83, 92, 93?] \\
\hline \multirow[t]{6}{*}{ (c) Dilution factor } & Not stated: $[16,18,23,73,86,94,95,98]$ \\
\hline & $1: 1[6,7,9,17,20,22,41,71,85,87-92,96,97]$ \\
\hline & $2: 1[93]$ \\
\hline & $4: 1[5]$ \\
\hline & $6: 4[19]$ \\
\hline & $1: 6[83]$ \\
\hline \multirow[t]{6}{*}{ (d) Incubation procedure } & Not stated: $[16,18,71,86,95,96]$ \\
\hline & $10 \min , \mathrm{RT}[6,7,20]$ \\
\hline & $\begin{array}{l}15 \min , \mathrm{RT} \\
{[5,9,17,19,22,23,41,73,85,87-91,97,98]}\end{array}$ \\
\hline & $20 \mathrm{~min}, \mathrm{RT}[83,92]$ \\
\hline & $>20 \min , 2^{\circ} \mathrm{C}[93]$ \\
\hline & $30 \min [94]$ \\
\hline \multirow[t]{2}{*}{ (e) Comparison } & No: $[16-18,20,22,71,82,83,85,88,90,91,94,95]$ \\
\hline & Yes: $[5-7,9,19,23,41,73,86,87,89,92,93,96-98]$ \\
\hline $\begin{array}{l}\text { (f) ... with inappropriate } \\
\text { methods }\end{array}$ & {$[6,7,9,19,23,41,73,86,87,89,92,93,96-98]$} \\
\hline $\begin{array}{l}\text { (g) ... with appropriate } \\
\text { methods }\end{array}$ & {$[5]^{*}$} \\
\hline \multirow{2}{*}{$\begin{array}{l}\text { (h) Did the BLA results fit to } \\
\text { the other parameters? }\end{array}$} & No: $[7,19,86,89,92,93$ (DAPI), 96,97] \\
\hline & Yes: $[5,23,41,93$ (FDA), 98] \\
\hline \multirow{2}{*}{$\begin{array}{l}\text { (i) Did the BLA results } \\
\text { meet the expectations } \\
\text { of the user(s)? }\end{array}$} & No: $[23,83,86]$ \\
\hline & Yes: $[5,7,16,18-20,22,41,71,82,85,87-98]$ \\
\hline
\end{tabular}

(a) to (i) see description in the text.

Not stated: Either no information was given by the authors, or the authors stated that the staining was conducted "according to the manufacturer's instructions", what means generally a dilution factor of 1:1, and an incubation time of 15 minutes.

*[5]: Decker registered the total bacterial counts (as $\log \mathrm{BC} / \mathrm{ml}$ ) and the CFU (as log CFU/ml), however gave no data regarding the $\mathrm{PE}$.

*[82]: "cell-free" physicochemical measurements to elucidate the mechanism of the BacLight staining procedure.

viability standard; 2.6 Preparation of the individual plaque viability standard, 2.7 Preparation of the pooled viability standard; 2.8 Staining protocol for Live/Dead ${ }^{\circledR}$ BacLight $^{\text {TM }}$ and 2.9 Fluorescence measurement and data analysis). Surprisingly, the calibration procedure of these authors [92] even seemed to work when samples and controls were fixed in $4 \%$ paraformaldehyde, and/or were stored for up to three months.

As a consequence of having no validation the utmost users rely in the manufacturer's advices regarding the 
dilution factor between the two stains SYTO 9 and PI. Only four research groups did not follow the recommended 1:1 dilution. Interestingly, their factors span a range from 1:6 up to 4:1 (line (c) in Table 3). This generally mirrors the seductive nature of the staining procedure [13] and the requests the researchers have towards an easy and quick application. The concern of Stocks [82] that the relative concentrations of PI, SYTO9 and the nucleic acids are of crucial importance is mostly neglected by the users.

At first glance the same holds true for the incubation procedure (line (d) in Table 3), however, this might be a more severe problem. Twenty-two of the users did not state the procedure or relied on the manufacturer's instructions. Some others reduced the recommended 15minute incubation to 10 minutes $[6,7,20]$, while others extended the incubation time between the BacLight stains and their samples to 20 or even 30 minutes [83,92-94]. However, the finding of Tawakoli et al. [7] that the stained cells under investigation changed or even lost their viability shortly after intercalation of the dyes suggests that the "simple" incubation time is a crucial and potentially destructive factor. It is to question whether a time of 10,20 or 30 minutes ("in the dark", but at room temperature, and only once at $2^{\circ} \mathrm{C}$ [93]) may exert a deteriorating effect on the outcome of the staining procedure. This is of specific importance when the influence of antibacterial substances is assessed like the widely used and often studied chlorhexidine (CHX) or essential oils (EO), which affect the integrity of the bacterial cell membrane.

All three phenomena - FRET and double staining $[41,82,83]$, potential impact of exopolymers [21], and the observation of decreasing vitality during the staining procedure [7] - point towards an overestimation of PI, i.e., of dead cells. For an example Tomás and colleagues assessed the effects of CHX in saliva as measured with the aid of the BLA [89-91]. Especially 30 seconds after rinsing with $\mathrm{CHX}$ they revealed a very strong bactericidal action. However, their magnitude was in line with former (independent) conventional plating assays of the same research group [99]. Noteworthy, this research group had acceptable outcomes with the use of the staining procedures and presented convincing data regarding the antibacterial effect of different CHX concentrations, rinsing regimes $[89,90]$ and influencing factors [91]. In sum, however, it cannot be cleared whether there is an artificial shifting towards "dead" values as long as no concomitant comparison with appropriate conventional parameters is made.

Different trials concerning comparisons were conducted by the BLA users (line (e) in Table 3), with the exception of [5] altogether with inappropriate methods. In our opinion (see next paragraph) only the plating efficiency $(\mathrm{PE})$ as a relative parameter is appropriate, but not the CFU. Decker [5] registered the total bacterial counts (BC) as well as the CFU, both parameters being the mathematical basis to calculate the PE [8]. Nevertheless, she did not determine the corresponding PE values. Therefore, the positive and negative conclusions regarding the reliability of her different staining procedures cannot be justified.

Assessments of CFU were conducted by different authors, either in independent earlier publications [99-101] before the authors switched to the usage of the BLA $[19,90,91]$, or simultaneously with their BLA measurements [7,19,23,86,89,92,96-98]. Quite astonishingly all these very different author groups tried to compare the relative parameter "percentage of vital bacteria", as monitored by the BLA, with the absolute parameter CFU as assessed by plate counting. No wonder that the counts did not fit with the BLA in 7 of the 9 cases (line (h) in Table 3).

Finally, we tried to judge whether the authors were satisfied with the outcome of the BLA (line (i) in Table 3). This was more or less true in the majority of cases, independent of validation and comparison, and independent of the agreement of the BLA with the other (inappropriate) methods. Some authors were nearly delighted $[92,93]$.

Taking all objective observations into consideration, incorrect statements were published by the users of the BLA. Some of the users $[6,7,21,23,41,71,82,83,86]$ even describe and discuss the shortcomings of their commercial stains. Similarly, as already mentioned, Davey [10] in her recent review criticizes some limitations or "stumbling blocks" in flow cytometry. No single stain or staining method has been found to be suitable for all organisms [102]. Consequently, the modus operandi of different fluorescent stains has even been described in several reviews (see for example [102-104]). The second limiting factor deserving consideration is the need for further method development and protocol adjustment, even when similar protocols have already been published. For example, microorganisms may need pretreatment, which may also be different for gram-positives and gramnegatives, such as the use of EDTA. Thus, such protocol modifications are necessary for each new bacterial species tested ("strain- and matrix-specific optimization of the protocol") $[10,97,105,106]$. Again, it should be noted that the dental biofilm comprises, in a conventional view, of as many as or even more than 1000 diverse species $[8,84]$ embedded in a complex matrix [8]. A current genetic analysis even discloses 10000 species-level phylotypes [107].

\section{Colony Forming Units (CFU) and Plating Efficiency (PE) for comparison with vital stains}

The only parameter that can be used for comparing the reliability of vital stains (of any kind) is the plating efficiency (PE). This is irrespective of the difficulties of 
determining "viability" via cultivation as mentioned above. $\mathrm{PE}$ can be calculated by relating plate counts (CFU) and total microscopic counts (MC), as conducted by Netuschil and coworkers with supragingival plaque biofilm bacteria ex vivo [108-110]. Table 4 (data taken from [8]) signifies a good relationship between Fluorescein Diacetate/Ethidium Bromide (FDA/EB) based vital fluorescence data (VF) and corresponding PE values. When PE and VF were assessed from the same plaque sample the PE resulted in lower values than VF (in 7 of 9 comparisons including about 500 samples, Table 4). This is to be expected because more microorganisms should be vital than viable.

Moreover, Table 4 illustrates that initial dental plaque consists mainly of bacteria that are either not culturable or are dead. This has been proven by cultivation [111] or by cultivation and concomitant vital fluorescence (VF) [108-110]. In two hour old plaque samples Weiger et al. [109] calculated a mean PE of 30\% compared to a mean value of $22 \%$ vital bacteria in VF (FDA/EB). In their study with 120 minute old adhering biofilm bacteria Tawakoli et al. [7] found vitalities ranging from $42 \%$ to $66 \%$ (cf. their Table 4).

PE data were not assessed in the investigation by Tawakoli et al. [7]. They discussed "a certain variance between the different combinations" of stains, which "resulted in three groups: equal distribution [2 stains], more dead bacteria vs. viable [1 stain], more viable vs. dead bacteria [2 stains]" (see the results in their article, Table 3). However, without an accompanying calculation of PE an important question remains to be answered: Which of these (groups of) vital stains reflect (or do not reflect) the microbial reality? Similar to other authors [19,23,86,89,92,96-98], Tawakoli et al. [7] assessed the
CFU, which only reflect the pure number of bacteria in their samples. No wonder that the latter authors state the following in their results: "A correlation between the number of bacteria detected with CFU and the number of viable bacteria, detected with staining techniques, could not be observed."

\section{Dependence of the results of vitality testing on the stain's concentration}

Stocks [82] clearly stated that not only the relative concentrations of PI and SYTO9, but also their relationship to DNA are of crucial importance. This equals Acridine Orange (AO), which is falsely named a vital stain, and which stains nucleic acids either green (this was wrongly believed to be vital) or red (this was wrongly believed to be dead). It could easily be shown that dilutions or concentrations of only factor 2 lead to remarkable shifts in the green/red images [8]. This clarifies that the so-called "vitality values," as assessed with $\mathrm{AO}$, are dependent on its concentration, on $\mathrm{pH}$ and other factors, as well as on the relationship of the dye (whether in an adequate concentration or not) to the actual amount of stainable nucleic acids, DNA and/or RNA. Citations from the MOLECULAR PROBES Product Information [81], including (I) that an "appropriate mixture" of the dyes is necessary for reliable testing, and (II) that the number of bacteria to be tested has to be known and standardized in a species-specific manner, clarifies that the aforementioned statement concerning $\mathrm{AO}$, in accordance with Stocks [82], also applies to the SYTO 9/PI stain.

However, no relevant concentration-dependency was found for the FDA/EB staining. Staining solutions containing the same basic concentration of FDA/EB were applied in different studies, where, due to differing study

Table 4 Vital fluorescence (VF\%) results compared to the corresponding bacteriological parameter plating efficiency (PE\%) (data taken from [8])

\begin{tabular}{|c|c|c|c|c|c|}
\hline Reference & $\mathrm{n}^{1}$ & Plaque age (Days) & VF $(\%) \pm S D$ & Relation $^{2}$ & $\mathrm{PE}(\%) \pm \mathrm{SD}$ \\
\hline \multirow[t]{3}{*}{ WEIGER et al. 1992 [108] } & 200 & 1 & $69.8 \pm 16.0$ & n.a. ${ }^{3}$ & $60.4 \pm 30.3$ \\
\hline & & 2 & $78.0 \pm 14.7$ & n.a. & $91.9 \pm 30.1$ \\
\hline & & 3 & $81.3 \pm 10.9$ & n.a. & $82.4 \pm 26.8$ \\
\hline \multirow[t]{3}{*}{ WEIGER et al. 1994 [115] } & 132 & 1 & $42.9 \pm 20.7$ & $<$ & $47.8 \pm 21.8$ \\
\hline & & 2 & $76.3 \pm 17.5$ & $>$ & $58.8 \pm 18.0$ \\
\hline & & 3 & $86.3 \pm 7.8$ & $>$ & $73.5 \pm 30.6$ \\
\hline \multirow[t]{3}{*}{ VON OHLE 1995 CF. [109] } & 211 & 1 & $57 \pm 18$ & $<$ & $75 \pm 35$ \\
\hline & & 2 & $73 \pm 20$ & $>$ & $53 \pm 20$ \\
\hline & & 3 & $79 \pm 18$ & $>$ & $55 \pm 20$ \\
\hline \multirow[t]{2}{*}{ NETUSCHIL et al. 1995 [110] } & 160 & 1 & $52.1 \pm 17.2$ & $>$ & $43.9 \pm 27.2$ \\
\hline & & 3 & $90.8 \pm 6.1$ & $>$ & $83.7 \pm 17.0$ \\
\hline
\end{tabular}

${ }^{1}$ Number of independent plaque samples.

${ }^{2}$ Rough relation between $\mathrm{VF}(\%)$ and $\mathrm{PE}(\%)$.

${ }^{3}$ n.a.: not available - in this first study different plaque samples (however, from one patient each) were taken for assessment of either $\mathrm{VF}(\%)$ or $\mathrm{PE}(\%)$. 
designs, the volumes of the used staining solutions ranged from $5 \mu \mathrm{l}[112,113]$ to $50 \mu \mathrm{l}[114]$, and even up to $500 \mu \mathrm{l}[110,115]$, without changing the outcomes of the VF assessments [8].

The majority of the commercial staining components act via passive physicochemical distribution patterns, which are assumed to be different in (real) viable and (real) dead microbial cells. This also holds true for EB; however the color of EB cannot change due to concentration, $\mathrm{pH}$ or other physicochemical parameters [8]. In contrast, the non-fluorescent FDA penetrates the cell membranes of living cells, and is cleaved only in a metabolically active cell by different enzymes, mainly esterases $[8,116,117]$, to yield the fluorescing Fluorescein. Thus, a functioning metabolism is a necessary prerequisite for positive intracellular (vital) staining. Similar to the red EB counter stain, the green Fluorescein staining is neither hampered nor changed by physicochemical effects.

Vital fluorescence assessments in dental biofilm research It is to question why the "traditional" VF stains of FDA and EB used in oral biofilm research should be replaced with other substances that exert a similar health risk (see next paragraph) and are not proven to be suitable and reliable in biofilm studies. Regarding FDA/EB, an assortment of existing publications (apart from numerous cell culture and cytotoxicity investigations) can be cited from research groups Netuschil [108-110,112,114,115, 118-124], Brecx [125-128], Arweiler/Auschill [113,129-143] and others [144-155]. In this context the FDA/EB vital fluorescence staining was routinely used together with Confocal Laser Scanning Microscopy (CLSM) [119,124,131, 134-136,139,140,143,153] to establish the three-dimensional vitality pattern of the (early) dental biofilm or to document the antibacterial effects of dental materials, mouthrinse solutions as well as food preservatives.

Worth noting is that the FDA/EB VF staining method discriminates very well between the bactericidal effects of diverse mouth rinse preparations $[8,110,113,120,123$,
$125,126,129,133,137,138,145]$. Also, due to easy handling and to the independency of calibration procedures as well as concentration and other physical and chemical parameters, the results obtained via FDA/EB staining can be compared between different studies and even between different research groups.

\section{Mutagenicity of staining solutions}

Tawakoli et al. [7] argue that EB, which stains by intercalation in DNA, is mutagenic. Without any question, this fact has to be taken into consideration [8]. Because high amounts of EB are used in genetic research around the world, research laboratories are aware of this compound and its carcinogenicity. The authors of this article often experienced deep negativity towards EB, and only upon mentioning the name of this compound amongst the laboratory staff caused great concern. Nevertheless, at four different universities in Germany (Tübingen, Homburg/Saarland, Dresden and Freiburg, 1980 till 2009) we received general permission from the safety authorities to dispose our FDA/EB staining solutions in the normal waste due to the very scarce amounts of EB used.

The handling procedures of EB correspond with sources found in the internet [Wikipedia, Ethidium bromide, June 2012, see \{further citations\} there]: "Ethidium bromide is not regulated as hazardous waste at low concentrations \{17\}." Due to its use in veterinary medicine as an anti-trypanosoma medicament $\{1\}$, its non-mutagenic effect in mice during a "subchronic carcinogenicity study" $\{11\}$ and its effect even as an antitumorigenic chemotherapeutic agent $\{12\}$ the "above studies do not support the commonly held idea that ethidium bromide is a potent mutagen in humans..." Nevertheless, Wikipedia recommends to be cautious and the "material should be handled according to the material safety data sheet..."

Ironically, the alternatives PI and the SYTO 9 are also potentially hazardous chemicals. Here also we would like to cite [81] the MOLECULAR PROBES Product

Table 5 Comparison of some staining principles in regard to their suitability for biofilm research

\begin{tabular}{|c|c|c|c|c|c|c|}
\hline \multirow[t]{2}{*}{ Staining principle } & \multirow[t]{2}{*}{$\begin{array}{c}\text { Stain(s) } \\
\text { (combinations) }\end{array}$} & \multicolumn{2}{|c|}{$\begin{array}{c}\text { Comparison with } \\
\text { microbiological data (PE) }\end{array}$} & \multirow[t]{2}{*}{$\begin{array}{l}\text { Concentration } \\
\text { independency }\end{array}$} & \multirow[t]{2}{*}{$\begin{array}{c}\text { Suitability for } \\
\text { biofilm research }\end{array}$} & \multirow[t]{2}{*}{$\begin{array}{l}\text { Potentially } \\
\text { mutagenic }\end{array}$} \\
\hline & & $\begin{array}{l}\text { Single species } \\
\text { in vitro }\end{array}$ & $\begin{array}{l}\text { Biofilm ex vivo } \\
\text { or in situ }\end{array}$ & & & \\
\hline Vital fluorescence (FDA/EB) cf. [8,110,112] & $\begin{array}{l}\text { Fluorescein diacetate, } \\
\text { Ethidium bromide }\end{array}$ & + & ++ & $\begin{array}{c}\text { Proven } \\
{[8,110,112-115]}\end{array}$ & $\begin{array}{c}\text { Proven } \\
\text { (cf. Table 4) }\end{array}$ & $+^{1}$ \\
\hline BacLight ${ }^{\oplus}$ (cf. Table 3) & $\begin{array}{c}\text { Syto } 9 \\
\text { Propidium iodide }\end{array}$ & - & - & $\begin{array}{l}\text { Questionable } \\
\text { (cf. Table 3) }\end{array}$ & $\begin{array}{l}\text { Questionable } \\
\text { (cf. Table 3) }\end{array}$ & $t^{2}$ \\
\hline Staining according to $[10,102]$ & Diverse substances & $?$ & $?$ & $\begin{array}{l}\text { Non-existing or } \\
\text { questionable }\end{array}$ & $\begin{array}{l}\text { Non-existing or } \\
\text { questionable }\end{array}$ & $?$ \\
\hline
\end{tabular}

${ }^{1}$ Proven.

${ }^{2}$ Generally to assume, partly proven.

?Partly known or not known or not available from the diverse substances. 
Information (IV): "Storage and Handling: Caution: Propidium iodide and SYTO 9 stain bind to nucleic acids. Propidium iodide is a potential mutagen, and we have no data addressing the mutagenicity or toxicity of the SYTO 9 stain. Both reagents should be used with appropriate care .... As with all nucleic acid stains, solutions containing these reagents should be poured through activated charcoal before disposal. The charcoal must then be incinerated to destroy the dyes."

Thus, it seems that the difference between EB and other intercalating dyes (for an example see [156]) is not their potential mutagenicity, but the fact that the mutagenicity of EB has been commonly known for decades. In contrast, laboratory staff and other users of these chemicals are not aware of the similar risk that PI, SYTO 9 and other nucleic stains could have.

\section{Summary}

Table 5 presents some "puzzle pieces" that are part of this debate. As pointed out (cf. Davey [10] as well as Pamp et al. [11]) a plethora of possibilities exist concerning vital stains, staining methods, and staining principles. For example, Tawakoli et al. [7] used combinations of several stains, which were in part related to the FDA/EB combination (FDA, cFDA, TCFDA and EB) or resembled more the BacLight drawer (SYTO 9/PI, Sytox red).

An inherent aspect concerning the suitability of staining methods is the dependency on the stains' concentrations of the results. Table 4 lists the literature showing the independency of concentration of the FDA/EB vital staining. In contrast, the evidence does not seem to exist for a vast majority of the other stains.

It is compelling that "vital stains" (or however they might be named) and, even more important, their numerous combinations are directly comparable to appropriate conventional bacteriological data. This cannot be the assessment of CFU, but of PE. As depicted in Table 4 corresponding data exists for FDA/EB. To the best of our knowledge this does not hold true for the often used BLA (cf. Table 3 and corresponding text).

In summary, our concluding statements are as follows:

- The nomenclature regarding "viability" and "vitality" should be used with appropriate care. Per definitionem no kind of stain used for bacteria can prove their "viability". Thus, such stains generally should be named "vital stains".

- According to the BLA manual itself and the corresponding literature, the kit is not suitable for natural multispecies biofilms research. The kit is meant for use on a single defined bacterial species in a concentration of staining solution that was determined following a thorough calibration procedure.
- As a consequence of the kit's limitations, there is a strong assumption that the results obtained with several stains are influenced not only by physical and chemical parameters, but also by the relationship between total bacterial counts (viable, vital or dead) and the amount of the stain used in the test. Thus, the vitality data collected are prone to a completely unknown percentage of artificial shifting.

- Contrarily, no corresponding concentrationdependency (or "relationship-dependency") was found with respect to FDA/EB. Moreover, the green intracellular (vital) Fluorescein staining originates only in metabolically active (bacterial) cells.

- Colony forming units (CFU) are not a useful parameter to compare to the results of "vitality staining". Instead the plating efficiency (PE) should be used, if possible to conduct.

- It is a common belief that EB is highly mutagenic. However, the documented data is controversial. EB seems not to be a hazardous mutagen in humans. In this respect, researchers and laboratory staff should be aware that alternative staining compounds may also be or even are mutagenic.

\section{Competing interests}

The authors declare that they have no competing interests.

\section{Authors' contributions}

NBA: Initiator of the review, vital fluorescence biofilm research regarding clinical controlled studies; LN: Main author, microbiology and 'dead and alive' discussion; TMA: CLSM research, Syto 9 and related compounds; AS: Mutagenicity of vital stains, refining and general support in editing. All authors read and approved the final manuscript.

\section{Acknowledgements}

The authors wish to thank Kristina Schmidt, MPH, RDH, praxisHochschule Cologne, Germany, for her help in editing the final version of the manuscript.

\section{Author details}

${ }^{1}$ Department of Periodontology, Dental School, Philipps-University Marburg, Marburg, Germany. ${ }^{2}$ praxisHochschule, Cologne, Germany. ${ }^{3}$ Department of Periodontology, Dental School, University of Berne, Berne, Switzerland.

Received: 5 November 2013 Accepted: 27 December 2013

Published: 11 January 2014

\section{References}

1. Mason CA, Hamer G, Bryers JD: The death and lysis of microorganisms in environmental processes. FEMS Microbiol Rev 1986, 39:373-401.

2. Roszak DB, Colwell RR: Survival strategies of bacteria in the natural environment. Microbiol Rev 1987, 51:365-379.

3. Kaprelyants AS, Kell DB: Rapid assessment of bacterial viability and vitality using rhodamine 123 and flow cytometry. J App/ Bacteriol 1992, 72:410-422.

4. Kaprelyants AS, Gottschal JC, Kell DB: Dormancy in non-sporulating bacteria. FEMS Microbiol Rev 1993, 104:271-285.

5. Decker E-M: The ability of direct fluorescence-based, two-colour assays to detect different physiological states of oral streptococci. Letters Appl Microbiol 2001, 33:188-192

6. Hannig C, Basche S, Burghardt T, Al-Ahmad A, Hannig M: Influence of a mouthwash containing hydroxyapatite microclusters on bacterial adherence in situ. Clin Oral Invest 2013, 17:805-814. doi:10.1007/s00784-012-0781-6. 
7. Tawakoli PN, Al-Ahmad A, Hoth-Hannig W, Hannig M, Hannig C: Comparison of different live/dead stainings for detection and quantification of adherent microorganisms in the initial oral biofilm. Clin Oral Invest 2013, 17:841-850. doi:10.1007/s00784-012-0792-3.

8. Netuschil L: Der Biofilm dentale Plaque - Antibakterielle Beeinflussung, Strukturaus-sagen und Modellentwicklungen auf Basis von Vitalfluoreszenzuntersuchungen [Dental Plaque as a Biofilm - Antibacteria Measures, Structure and Models as developed due to vital fluorescence assessments]. In Ph.D. thesis, Faculty of Medicine Carl Gustav Carus, TU Dresden 2004. SLUB, Saxonian State University Library:1-274. Signature 3206 40053001.

9. Rupf S, Idlibi AN, Marrawi FA, Hannig M, Schubert A, von Mueller L, Spitzer W, Holtmann H, Lehmann A, Rueppell A, Schindler A: Removing biofilms from microstructured titanium ex vivo: a novel approach using atmospheric plasma technology. PLoS One 2011, 6(10):e25893. doi:10.1371/journal.pone.0025893.

10. Davey HM: Life, death, and in-between: meanings and methods in microbiology. Appl Environ Microbiol 2011, 77:5571-5576.

11. Pamp SJ, Sternberg C, Tolker-Nielsen T: Insight into the microbial multicellular lifestyle via flow-cell technology and confocal microscopy. Cytometry A 2009, 75A:90-103.

12. Amor KB, Breeuwer $P$, Verbaarschot $P$, Rombouts FM, Akkermans ADL, de Vos WM, Abee T: Multiparametric flow cytometry and cell sorting for the assessment of viable, injured, and dead Bifidobacterium cells during bile salt stress. Appl Environ Microbiol 2002, 68:5209-5216.

13. Shi L, Günther S, Hübschmann T, Wick LY, Harms H, Müller S: Limits of propidium iodide as a cell viability indicator for environmental bacteria. Cytometry A 2007, 71A:592-598.

14. Mailaender C, Reiling N, Engelhardt H, Bossmann S, Ehlers S, Niederweis M: The MspA porin promotes growth and increases antibiotic susceptibility of both Mycobacterium bovis BCG and Mycobacterium tuberculosis. Microbiology 2004, 150:853-864.

15. Haugland RP: The Handbook - a guide to fluorescent probes and labeling technologies. In Eugene, Molecular Probes. 10th edition. 2005. Section 15.3; sheet mp07007.

16. Zhu M, Takenaka S, Sato M, Hoshino E: Influence of starvation and biofilm formation on acid resistance of Streptococcus mutans. Oral Microbiol Immunol 2001, 16:24-27.

17. Bürgers R, Witecy C, Hahnel S, Gosau M: The effect of various topical periimplantitis antiseptics on Staphylococcus epidermidis, Candida albicans, and Streptococcus sanguinis. Arch Oral Biol 2012, 57:940-947.

18. Rüttermann S, Bergmann N, Beikler T, Raab WH, Janda R: Bacterial viability on surface-modified resin-based dental restorative materials. Arch Oral Biol 2012, 57:1512-1521.

19. Pan P, Barnett ML, Coelho J, Brogdon C, Finnegan MB: Determination of the in situ bactericidal activity of an essential oil mouthrinse using a vital stain method. J Clin Periodontol 2000, 27:256-261

20. Hope CK, Clements D, Wilson M: Determining the spatial distribution of viable and nonviable bacteria in hydrated microcosm dental plaques by viability profiling. J Appl Microbiol 2002, 93:448-455.

21. Caldwell DE, Wolfaardt GM, Korber DR, Lawrence JR: Do bacterial communities transcend Darwinism? Adv Microb Ecol 1997, 15:105-191.

22. Korber DR, Choi A, Wolfaardt GM, Ingham SC, Caldwell DE: Substratum topography influences susceptibility of Salmonella enteritidis biofilms to trisodium phosphate. Appl Environ Microbiol 1997, 63:3352-3358.

23. Giertsen E, Guggenheim B, Thurnheer T, Gmür R: Microbiological aspects of an in situ model to study effects of antimicrobial agents on dental plaque ecology. Eur J Oral Sci 2000, 108:403-411.

24. Barcina I, González JM, Iriberri J, Egea L: Effect of visible light on progressive dormancy of Escherichia coli cells during the survival process in natural fresh water. Appl Environ Microbio/ 1989, 55:246-251.

25. Barer MR, Gribbon LT, Harwood CR, Nwoguh CE: The viable but non-culturable hypothesis and medical bacteriology. Rev Med Microbiol 1993, 4:183-191.

26. Bogosian G, Sammons LE, Morris PJL, O'Neil JP, Heitkamp MA, Weber DB: Death of the Escherichia coli K-12 strain W3110 in soil and water Appl Environ Microbiol 1996, 62:4114-4120.

27. Bogosian G, Morris PJL, O'Neil JP: A mixed culture recovery method indicates that enteric bacteria do not enter the viable but nonculturable state. Appl Environ Microbiol 1998, 64:1736-1742.

28. Bowden GHW, Hamilton IR: Survival of oral bacteria. Crit Rev Oral Biol Med 1998, 9:54-85.
29. Button DK, Schut F, Quang P, Martin R, Robertson BR: Viability and isolation of marine bacteria by dilution culture: theory, procedures, and initial results. Appl Environ Microbiol 1993, 59:881-891.

30. Colwell RR: Nonculturable but still viable and potentially pathogenic. Zentralbl Bakteriol 1993, 279:154-156.

31. Colwell RR, Brayton PR, Grimes DJ, Roszak DB, Huq SA, Palmer LM: Viable but nonculturable Vibrio cholerae and related pathogenes in the environment: implications for the release of genetically engineered microorganisms. Biotechniques 1985, 3:817-820.

32. Dawe LL, Penrose WR: "Bactericidal" property of seawater: death or debilitation? Appl Environ Microbiol 1978, 35:829-833.

33. Duncan S, Glover LA, Killham K, Prosser Jl: Luminescence-based detection of activity of starved and viable but nonculturable bacteria. App/ Environ Microbiol 1994, 60:1308-1316.

34. González JM, Iriberri J, Egea L, Barcina I: Characterization of culturability, protistan grazing, and death of enteric bacteria in aquatic ecosystems. Appl Environ Microbiol 1992, 58:998-1004.

35. Gribbon LT, Barer MR: Oxidative metabolism in nonculturable Helicobacter pylori and Vibrio vulnificus cells studied by substrateenhanced tetrazolium reduction and digital image processing. Appl Environ Microbiol 1995, 61:3379-3384.

36. Höfle M: Long-term changes in chemostat cultures of Cytophaga johnsonae. Appl Environ Microbiol 1983, 46:1045-1053.

37. Hood MA, MacDonell MT: Distribution of ultramicrobacteria in a Gulf Coast estuary and induction of ultramicrobacteria. Microb Ecol 1987, 14:113-127.

38. Kell DB, Ryder HM, Kaprelyants AS, Westerhoff HV: Quantifying heterogeneity: flow cytometry of bacterial cultures. Antonie Van Leeuwenhoek 1991, 60:145-158.

39. Koch AL: What size should a bacterium be? A question of scale. Ann Rev Microbiol 1996, 50:317-348.

40. Kogure K, Simidu U, Taga N: A tentative direct microscopic method for counting living marine bacteria. Can J Microbiol 1979, 25:415-420.

41. Korber DR, Choi A, Wolfaardt GM, Caldwell DE: Bacterial plasmolysis as a physical indicator of viability. App/ Environ Microbiol 1996, 62:3939-3947.

42. McKay AM: Viable but non-culturable forms of potentially pathogenic bacteria in water. Lett Appl Microbiol 1992, 14:129-135.

43. Morgan JAW, Rhodes G, Pickup RW: Survival of nonculturable Aeromonas salmonicida in lake water. Appl Environ Microbiol 1993, 59:874-880.

44. Nebe-von Caron G, Stephens P, Badley RA: Assessment of bacterial viability status by flow cytometry and single cell sorting. J Appl Microbiol 1998, 84:988-998.

45. Nilsson L, Oliver JD, Kjelleberg S: Resuscitation of Vibrio vulnificus from the viable but nonculturable state. J Bacterio/ 1991, 173:5054-5059.

46. Nyström T: The trials and tribulations of growth arrest. Trends Microbiol 1995, 3:131-136.

47. Postgate JR: Death in macrobes and microbes. In: Gray TRG, Postgate JR (Eds.): The survival of vegetative microbes. Symp Soc Gen Microbiol 1977, 26:1-19.

48. Postgate JR, Hunter JR: The survival of starved bacteria. J Gen Microbiol 1962, 29:233-263.

49. Rose AS, Ellis AE, Munro ALS: Evidence against dormancy in the bacterial fish pathogen Aeromonas salmonicida subsp. salmonicida. FEMS Microbiol Lett 1990, 68:105-107.

50. Roszak DB, Colwell RR: Metabolic activity of bacterial cells enumerated by direct viable count. Appl Environ Microbiol 1987, 53:2889-2893.

51. Roszak DB, Grimes DJ, Colwell RR: Viable but nonrecoverable stage of Salmonella enteritidis in aquatic systems. Can J Microbiol 1984, 30:334-338.

52. Stevenson LH: A case for bacterial dormancy in aquatic systems. Microb Ecol 1978, 4:127-133.

53. Whitesides MD, Oliver JD: Resuscitation of vibrio vulnificus from the viable but nonculturable state. Appl Environ Microbiol 1997, 63:1002-1005.

54. Wilson M, Lindow SE: Relationship of total viable and culturable cells in epiphytic populations of Pseudomonas syringae. Appl Environ Microbiol 1992, 58:3908-3913.

55. Winterberg H: Zur Methodik der Bakterienzählung [Concerning methods to count bacteria]. Zeitschr Hyg 1898, 29:75-93.

56. Hehewerth FH: Die microscopische Zählungsmethode der Bakterien von Alex. Klein und einige Anwendungen derselben [The microscopic counting method of Alex. Klein and some applications thereof]. Arch Hyg 1901, 39:321-389.

57. Kelly $C D$, Rahn O: The growth rate of individual bacterial cells. J Bacteriol 1932, 23:147-153. 
58. Ziegler NR, Halvorson HO: Application of statistics to problems in bacteriology. IV. Experimental comparison of the dilution method, the plate count, and the direct count for the determination of bacterial populations. J Bacterio/ 1935, 29:609-634.

59. Jennison MW: Relations between plate counts and direct microscopic counts of Escherichia coli during the logarithmic growth period. J Bacteriol 1937, 33:461-477.

60. Jannasch HW, Jones GE: Bacterial populations in seawater as determined by different methods of enumeration. Limnol Oceanogr 1959, 4:128-139.

61. Razumov AS: Mikrobiologija 1932, 1:131-146. as cited by Staley and Konopka 1985 (cf. [62, 63]).

62. Staley JT, Konopka A: Measurement of in situ activities of nonphotosynthetic micro-organisms in aquatic and terrestrial habitants. Ann Rev Microbiol 1985, 39:321-346.

63. Amann Rl, Ludwig W, Schleifer K-H: Phylogenetic identification and in situ detection of individual microbial cells without cultivation. Microbio/ Rev 1995, 59:143-169.

64. Fraser CG: The action of methylene-blue and certain other dyes on living and dead yeast. J Phys Chem 1920, 24:741-748.

65. Henrici AT: Differential counting of living and dead cells of bacteria. Proc Soc Exp Biol Med 1923, 20:293-295.

66. Rahn O, Barnes MN: An experimental comparison of different criteria of death in yeast. J Gen Physiol 1933, 16:579-592.

67. Gay FP, Clark AR: The differentiation of living from dead bacteria by staining reactions. J Bacteriol 1934, 27:175-189.

68. Strugger S: Die fluoreszenzmikroskopische Unterscheidung lebender und toter Zellen mit Hilfe der Acridinorangefärbung [Fluorescencemicroscopic differentiation of living and dead cells with the aid of Acridinorange staining]. Dtsch Tierärztl Wschr 1941, 49:525-527.

69. Postgate JR: Viable counts and viability. Meth Microbiol 1969, 1:611-628

70. Azam F: Introduction, history, and overview: The 'methods' to our madness. Meth Microbiol 2001, 30:1-12.

71. Hope CK, Wilson M: Analysis of the effects of chlorhexidine and oral biofilm vitality and structure based on viability profiling and an indicator of membrane integrity. Antimicrob Agents Chemother 2004, 48:1461-1468.

72. Amann R, Springer N, Ludwig W, Görtz H-D, Schleifer K-H: Identification in situ and phylogeny of uncultured bacterial endosymbionts. Nature 1991, 351:161-163.

73. Vollertsen J, Jahn A, Nielsen JL, Hvitved-Jacobsen T, Nielsen PH: Comparison of methods for determination of microbial biomass in wastewater. Water Res 2001, 35:1649-1658.

74. Barer MR, Smith RJ, Cooney RP, Kimmitt PT: Relationships between culturability, activity and virulence in pathogenic bacteria. $J$ Infect Chemother 2000, 6:108-111.

75. Colwell RR: Viable but nonculturable bacteria: a survival strategy. J Infect Chemother 2000, 6:121-125.

76. Kell DB, Kaprelyants AS, Weichart DH, Harwood CR, Barer MR: Viability and activity in readily culturable bacteria: a review and discussion of the practical issues. Antonie Von Leeuwenhoek 1998, 73:169-187.

77. Nystrom T: Not quite dead enough: on bacterial life, culturability, senescence, and death. Arch Microbiol 2001, 176:159-164.

78. Yamamoto $\mathrm{H}$ : Viable but nonculturabel state as a general phenomenon of non-spore-forming bacteria, and its modeling. J Infect Chemother 2000, 6:112-114.

79. Lahtinen SJ, Ahokoski H, Reinikainen JP, Gueimonde M, Nurmi J, Ouwehand AC, Salminen SJ: Degradation of $16 \mathrm{~S}$ rRNA and attributes of viability of viable but nonculturable probiotic bacteria. Lett App/ Microbiol 2008, 46:693-698.

80. Lahtinen SJ, Gueimonde M, Ouwehand A, Reinikainen JP, Salminen S: Probiotic bacteria may become dormant during storage. Appl Environ Microbiol 2005, 71:1662-1663

81. Molecular probes: Product information LIVE/DEAD ${ }^{\circledR}$ BacLight $^{\mathrm{TM}}$ bacterial viability Kit. 2001.

82. Stocks SM: Mechanism and use of the commercially available viability stain, BacLight. Cytometry A 2004, 61A:189-195.

83. Berney M, Hammes F, Bosshard F, Weilenmann H-U, Egli T: Assessment and interpretation of bacterial viability by using the LIVE/DEAD BacLight Kit in combination with flow cytometry. App Environ Microbiol 2007, 73:3283-3290.

84. Haffajee AD, Socransky SS, Feres M, Ximenez-Fyvie LA: Plaque microbiology in health and disease. In Dental plaque revisited. Edited by Newman HN, Wilson M. Chippenham: BioLine Antony Rowe Ltd.; 1999:255-282.
85. Otten MPT, Busscher HJ, van der Mei HC, Abbas F: Retention of antimicrobial activity in plaque and saliva following mouthrinse use in vivo. Caries Res 2010, 44:459-464.

86. Lahtinen SJ, Gueimonde M, Ouwehand AC, Reinikainen JP, Salminen SJ: Comparison of four methods to enumerate probiotic bifidobacteria in a fermented food product. Food Microbiol 2006, 23:571-577.

87. Bürgers R, Eidt A, Frankenberger R, Rosentritt M, Schweikl H, Handel G, Hahnel S: The anti-adherence activity and bactericidal effect of microparticulate silver additives in composite resin materials. Arch Oral Biol 2009, 54:595-601.

88. Gosau M, Hahnel S, Schwarz F, Gerlach T, Reichert TE, Bürgers R: Effect of six different peri-implantitis disinfection methods on in vivo human oral biofilm. Clin Oral Implants Res 2010, 21:866-872.

89. Tomás I, García-Caballero L, Cousido MC, Limeres J, Álvarez M, Diz P: Evaluation of chlorhexidine subtantivity on salivary flora by epifluorescence microscopy. Oral Dis 2009, 15:428-433.

90. Cousido MC, Tomás Carmona I, Garcia-Caballero L, Limeres J, Álvarez M, Diz $P$ : In vivo substantivity of $0.12 \%$ and $0.2 \%$ chlorhexidine mouthrinses on salivary bacteria. Clin Oral Invest 2010, 14:397-402

91. Tomás I, Cousido MC, García-Caballero L, Rubido S, Limeres J, Diz P: Substantivity of a single chlorhexidine mouthwash on salivary flora: influence of intrinsic and extrinsic factors. J Dentistry 2010, 38:541-546.

92. Filoche SK, Coleman MJ, Angker L, Sissons CH: A fluorescence assay to determine the viable biomass of microcosm dental plaque biofilms. J Microbiol Methods 2007, 69:489-496.

93. Quéric N-V, Soltwedel T, Arntz WE: Application of a rapid direct viable count method to deep-sea sediment bacteria. J Microbiol Methods 2004, 57:351-367.

94. van der Mei HC, White DJ, Atema-Smit J, van de Belt-Gritter E, Busscher HJ: A method to study sustained antimicrobial activity of rinse and dentifrice components on biofilm viability in vivo. J Clin Periodontol 2006, 33:14-20.

95. Neilands J, Petersson LG, Beighton D, Svensäter G: Fluoride-supplemented milk inhibits acid tolerance in root caries biofilms. Caries Res 2012, 46:156-160.

96. Shen Y, Stojicic S, Haapasalo M: Bacterial viability in starved and revitalized biofilms: comparison of viability staining and direct culture. J Endod 2010, 36:1820-1823.

97. Alakomi H-L, Mättö J, Virkajärvi I, Saarela M: Application of a microplate scale fluorochrome staining assay for the assessment of viability of probiotic preparations. J Microbiol Meth 2005, 62:25-35.

98. Welin-Neilands J, Svensäter G: Acid tolerance of biofilm cells of Streptococcus mutans. Appl Environ Microbiol 2007, 73:5633-5638.

99. Tomás I, Cousido MC, Tomás M, Limeres J, García-Caballero L, Diz P: In vivo bactericidal effect of $0.2 \%$ chlorhexidine but not $0.12 \%$ on salivary obligate anaerobes. Arch Oral Biol 2008, 53:1186-1191.

100. Pan PH, Finnegan MB, Sturdivant $L$, Barnett ML: Comparative antimicrobial activity of an essential oil and an amine fluoride/stannous fluoride mouthrinse in vitro. J Clin Periodontol 1999, 26:474-476.

101. Fine DH, Furgang D, Barnett ML: Comparative antimicrobial activities of antiseptic mouthrinses against isogenic planktonic and biofilm forms of Actinobacillus actinomycetemcomitans. J Clin Periodontol 2001, 28:697-700.

102. Davey HM, Kell DB, Weichart DH, Kaprelyants AS: Estimation of microbial viability using flow cytometry. Curr Protoc Cytom 2004, 11:11.3.1-11.3.21.

103. Lloyd D, Hayes AJ: Vigour, vitality and viability of microorganisms. FEMS Microbiol Lett 1995, 133:1-7.

104. Nebe-von-Caron G, Stephens PJ, Hewitt CJ, Powell JR, Badley RA: Analysis of bacterial function by multi-colour fluorescence flow cytometry and single cell sorting. J Microbiol Methods 2000, 42:97-114.

105. Auty MAE, Gardiner GE, McBrearty SJ, O'Sullivan E, Mulvihill DM, Collins JK, Fitzgerald GF, Stanton C, Ross RP: Direct in situ viability assessment of bacteria in probiotic dairy products using viability staining in conjunction with confocal scanning laser microscopy. Appl Environ Microbiol 2001, 55:420-425

106. Brehm-Stecher BF, Johnson EA: Single-cell microbiology: tools, technology and applications. Microbiol Mol Biol Rev 2004, 68:538-559.

107. Keijser BJ, Zaura E, Huse SM, van der Vossen JM, Schuren FH, Montijn RC, ten Cate JM, Crielaard W: Pyrosequencing analysis of the oral microflora of healthy adults. J Dent Res 2008, 87:1016-1020.

108. Weiger R, Netuschil L, Brecx M: Relationship between bacterial counts, microbial vitality and the accumulation of supragingival dental plaque in humans. J Periodont Res 1992, 27:575-580. 
109. Weiger R, Netuschil L, von Ohle C, Brecx M: Microbial vitality of supragingival dental plaque during initial stages of experimental gingivitis in humans. J Periodont Res 1995, 30:204-209.

110. Netuschil L, Weiger R, Preisler R, Brecx M: Plaque bacteria counts and vitality during chlorhexidine, meridol and listerine mouthrinses. Eur J Oral Sci 1995, 103:355-361.

111. Mikkelsen $L$ : Influence of sucrose intake on saliva and number of microorganisms and acidogenic potential in early dental plaque. Microb Ecol Health Dis 1993, 6:253-264.

112. Netuschil $L$, Reich $E$, Brecx M: Direct measurement of the bactericidal effect of chlorhexidine on human dental plaque. J Clin Periodontol 1989, 16:484-488.

113. Arweiler N, Donos N, Netuschil L, Sculean A, Reich E: Clinical and antibacterial effect of tea tree oil. Clin Oral Invest 2000, 4:70-73.

114. Weiger R, Netuschil L, Brecx M: Comparison of early human dental plaque formation on vestibular and approximal enamel surfaces in situ. J West Soc Periodontol Periodontal Abstr 1992, 40:101-104. / Erratum 41: 10.

115. Weiger R, Friedrich C, Netuschil L, Schlagenhauf U: Effect of a chlorhexidinecontaining varnish (Cervitec $\left.{ }^{\oplus}\right)$ on microbial vitality and accumulation of supragingival dental plaque in humans. Caries Res 1994, 28:267-271.

116. Guilbault GG, Kramer DN: Fluorometric determination of lipase, acylase, alpha- and gamma-chymotrypsin and inhibitors of these enzymes. Anal Chem 1964, 36:409-412.

117. Medzon EL, Brady ML: Direct measurement of acetylesterase in living protist cells. J Bacteriol 1969, 97:402-415.

118. Netuschil L: Vitalfärbung von Plaque-Mikroorganismen mit Fluoresceindiacetat und Ethidiumbromid [Staining of plaque microorganisms with Fluorescein diacetate and Ethidium bromide]. Dtsch zahnärztl Z 1983, 38:914-917.

119. Netuschil L, Reich E, Unteregger G, Sculean A, Brecx M: A pilot study of confocal laser scanning microscopy for the assessment of undisturbed dental plaque vitality and topography. Arch Oral Biol 1998, 43:277-285.

120. Brecx M, Netuschil L, Reichert B, Schreil G: Efficacy of Listerine, Meridol and Chlorhexidine mouthrinses on plaque, gingivitis and plaque bacteria vitality. J Clin Periodontol 1990, 17:292-297.

121. Hahn R, Weiger R, Netuschil L, Brüch M: Microbial accumulation and vitality on different restorative materials. Dent Mater 1993, 9:312-316.

122. Gehlen I, Netuschil L, Georg T, Reich E, Berg R, Katsaros C: The influence of a $0.2 \%$ chlorhexidin mouthrinse on plaque regrowth in orthodontic patients. A randomized prospective study. Part 2: bacteriological parameters. J Orofac Orthop 2000, 61:138-148.

123. Schlagenhauf U, Horlacher V, Netuschil L, Brecx M: Repeated subgingival oxygen irrigations in untreated periodontal patients. J Clin Periodontol 1994, 21:48-50.

124. Auschill TM, Arweiler NB, Brecx M, Reich E, Sculean A, Netuschil L: The effect of dental restorative materials on dental biofilm. Eur J Oral Sci 2002, 110:48-53.

125. Brecx M, Brownstone E, MacDonald L, Gelskey S, Cheang M: Efficacy of Listerine ${ }^{\circledast}$, Merido $^{\circledR}$ and chlorhexidine mouthrinses as supplements to regular tooth-cleaning measures. J Clin Periodontol 1992, 19:202-207.

126. Brecx M, MacDonald LL, Legary K, Cheang M, Forgay MGE: Long-term effects of Merido $^{\circledR}$ and chlorhexidine mouthrinses on plaque, gingivitis, staining, and bacterial vitality. J Dent Res 1993, 72:1194-1197.

127. Gelskey S, Brecx M, Netuschil L, MacDonald L, Brownstone E, Stoddart M: Vital fluorescence: a new measure of periodontal treatment effect. J Can Dent Assoc 1993, 59:615-618.

128. von Ohle C, Weiger R, Decker E, Schlagenhauf U, Brecx M: The efficacy of a single pocket irrigation on subgingival microbial vitality. Clin Oral Invest 1998, 2:84-90

129. Arweiler NB, Netuschil L, Reich E: Alcohol-free mouthrinse solutions to reduce supra-gingival plaque regrowth and vitality. A controlled clinical study. J Clin Periodontol 2001, 28:168-174

130. Sculean A, Auschill TM, Donos N, Brecx M, Arweiler NB: Effect of an enamel matrix protein derivative (Emdogain ${ }^{\circledast}$ ) on ex vivo dental plaque vitality. J Clin Periodontol 2001, 28:1074-1078.

131. Auschill TM, Arweiler NB, Netuschil L, Brecx M, Reich E, Sculean A: Spatial distribution of vital and dead microorganisms in dental biofilms. Arch Oral Biol 2001, 46:471-476.

132. Arweiler NB, Auschill TM, Donos N, Sculean A: Antibacterial effect of an enamel matrix derivative on in vivo dental biofilm vitality. Clin Oral Invest 2002, 6:205-209.

133. Arweiler NB, Auschill TM, Baguley N, Netuschil L, Sculean A: Efficacy of an amine fluoride-triclosan mouthrinse as compared to the individual active ingredients. J Clin Periodontol 2003, 30:192-196.
134. Auschill TM, Hellwig E, Sculean A, Hein N, Arweiler NB: Impact of the intraoral location on the rate of biofilm growth. Clin Oral Invest 2004, 8:97-101.

135. Arweiler NB, Hellwig E, Sculean A, Hein N, Auschill TM: Individual vitality pattern of in situ dental biofilms at different locations in the oral cavity. Caries Res 2004, 38:442-447

136. Auschill TM, Hein N, Hellwig E, Follo M, Sculean A, Arweiler NB: Effect of two antimicrobial agents on early in situ biofilm formation. J Clin Periodontol 2005, 32:147-152.

137. Arweiler NB, Böhnke N, Sculean A, Hellwig E, Auschill TM: Differences in efficacy of two commercial $0.2 \%$ chlorhexidine mouthrinse solutions: a 4-day plaque re-growth study. J Clin Periodontol 2006, 33:334-339.

138. Auschill TM, Deimling D, Hellwig E, Arweiler NB: Antibacterial effect of two toothpastes following a single brushing. Oral Health Prev Dent 2007, 5:25-32.

139. Al-Ahmad A, Wiedmann-Al-Ahmad M, Auschill TM, Follo M, Braun G, Hellwig E, Arweiler NB: Effects of commonly used food preservatives on biofilm formation of Streptococcus mutans in vitro. Arch Oral Biol 2008, 53:765-772.

140. Arweiler NB, Lenz R, Sculean A, Al-Ahmad A, Hellwig E, Auschill TM: Effect of food preservatives on in situ biofilm formation. Clin Oral Invest 2008, 12:203-208.

141. Arweiler NB, Pergola G, Kuenz J, Hellwig E, Sculean A, Auschill TM: Clinical and antibacterial effect of an anti-inflammatory toothpaste formulation with Scutellaria baicalensis extract on experimental gingivitis. Clin Oral Invest 2011, 15:909-913.

142. Arweiler NB, Auschill TM, Sculean A: Antibacterial effect of taurolodine (2\%) on established dental plaque biofilm. Clin Oral Invest 2012, 16:499-504.

143. Arweiler NB, Netuschil L, Beier D, Grunert S, Heumann C, Altenburger MJ, Sculean A, Nagy K, Al-Ahmad A, Auschill TM: Action of food preservatives on 14-days dental biofilm formation, biofilm vitality, and biofilm-derived enamel demineralisation in situ. Clin Oral Invest 2013: [Epub ahead of print] doi:10.1007/s00784-013-1053-9.

144. Botzenhart K, Heizmann W, Sedaghat S, Heeg P, Hahn T: Bacterial colonization and occurrence of legionella pneumophila in warm and cold water, in faucet aerators, and in drains of hospitals. Zbl Bakt Hyg 1986, B183:79-85.

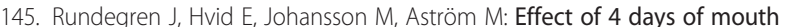
rinsing with delmopinol or chlorhexidine on the vitality of plaque bacteria. J Clin Periodontol 1992, 19:322-325.

146. Herles S, Olsen S, Afflitto J, Gaffar A: Chemostat flow cell system: an in vitro model for the evaluation of antiplaque agents. J Dent Res 1994, 73:1748-1755.

147. Kourkouta S, Walsh TF, Davis LG: The effect of porcelain laminate veneers on gingival health and bacterial plaque characteristics. J Clin Periodontol 1994, 21:638-640.

148. Gaffar A, Afflitto J, Nabi N, Herles S, Kruger I, Olsen S: Recent advances in plaque, gingivitis, tartar and caries prevention technology. Intern Dent J 1994, 44:63-70.

149. Gaffar A, Afflitto J, Nabi N: Chemical agents for the control of plaque and plaque microflora: an overview. Eur J Oral Sci 1997, 105:502-507.

150. Mullally BH, James JA, Coulter WA, Linden GJ: The efficacy of a herbalbased toothpaste on the control of plaque and gingivitis. J Clin Periodontol 1995, 22:686-689.

151. Walsh TF, Ünsal E, Davis LG, Yilmaz Ö: The effect of irrigation with chlorhexidine or saline on plaque vitality. J Clin Periodontol 1995, 22:262-264.

152. Walsh TF, Ünsal E, Varella-Centelles P: Comparison of digitised and visual plaque vitality measurement. J Clin Periodonto/ 1995, 22:653-654

153. Zaura-Arite E, van Marle J, ten Cate JM: Confocal microscopy study of undisturbed and chlorhexidine-treated dental biofilm. J Dent Res 2001, 80:1436-1440

154. König J, Storcks V, Kocher T, Bössmann K, Plagmann H-C: Anti-plaque effect of tempered $0.2 \%$ chlorhexidine rinse: an in vivo study. J Clin Periodontol 2002, 29:207-210

155. Hannig C, Hannig M, Rehmer O, Braun G, Hellwig E, Al-Ahmad A: Fluorescence microscopic visualization and quantification of initial bacterial colonization on enamel in situ. Arch oral Biol 2007, 52:1048-1056.

156. Wojcik K, Dobrucki JW: Interaction of a DNA intercalator DRAQ5, and a minor groove binder SYTO17, with chromatin in live cells - influence of chromatin organization and histone-DNA interactions. Cytometry A 2008, 73:555-562.

doi:10.1186/1472-6831-14-2

Cite this article as: Netuschil et al:: Confusion over live/dead stainings for the detection of vital microorganisms in oral biofilms - which stain is suitable? BMC Oral Health 2014 14:2 